\title{
DeVeloping The MATHEMATiCs CONCEPTUAL UNDERSTANDing AND Procedural FluenCy THROUgh DidACTICAL ANTICIPATORY APPROACH EQUIPPED WITH TEACHING AIDS
}

\author{
Asmida $^{1)}$, Sugiatno ${ }^{2)}$, Agung Hartoyo ${ }^{3)}$ \\ 1) Universitas Tanjungpura, Pontianak, Indonesia \\ E-mail:asmida45@yahoo.com \\ ${ }^{2)}$ Universitas Tanjungpura, Pontianak, Indonesia \\ E-mail:giatno66@gmail.com \\ 2) Universitas Tanjungpura, Pontianak, Indonesia \\ E-mail:ag_hartoyo@yahoo.com
}

\begin{abstract}
The students' conceptual understanding and procedural fluency have not been yet integrated into the mathematics learning as the teachers' common mathematics textbook has not explicitly explained the conceptual understanding and procedural fluency in solving the mathematical problems that the teachers have not yet connected it to the mathematics learning. The interview result shows that the students only memorize the procedures without understanding. If the procedure is continuously applied, it is predicted that the students may face the epistemological obstacles in solving the mathematical problems. This research aims at developing the students' mathematics conceptual understanding and procedural fluency through the Didactic Anticipatory Approach equipped with the teaching aids in learning the operations of integer multiplication at Junior High School in Grade VIII. This pedagogical action research involves 14 students. The research data are collected using tests, interviews, voice recorders and cameras. The result shows that learning mathematics through the Didactic Anticipatory Approach equipped with teaching aids may develop the students' conceptual understanding and mathematics procedural fluency marked by the reduced students' epistemological obstacles. However, they are not yet been completely resolved. The students' conceptual understanding and mathematics procedural fluency also supported with the average posttest score higher than that of the pretest score.
\end{abstract}

Keywords: Conceptual understanding; Didactic anticipatory approach; Procedural fluency

\section{INTRODUCTION}

The National Research Council (NRC) document states that there are five components in mathematic competence, including conceptual understanding and procedural fluency (NRC, 2001). Conceptual understanding is knowing and understanding a mathematic concept as well as relating one concept to the other (NAEP, 2002; Isleyen \& Isik, 2003; Chadwick, 2009; Walle et al., 2010). Meanwhile, procedural fluency is the students' skill to flexibly, efficiently, and accurately solve the mathematical problems (NRC, 2001; McClure, 2014).

A good conceptual understanding may support the development of procedural fluency in multi-digit calculation and become a powerful device to solve the mathematical problems (NRC, 2001). This statement is in line with that mentioned in the Regulation of the Minister of National Education (Permendiknas) (2006) that procedural fluency may be conducted after understanding the concept, explaining the relationship, and application. However, it indicates that the students' conceptual understanding and procedural fluency have not been well integrated in the mathematics learning.

One of the causes is that the teachers' mathematics handbook does not explicitly explain the conceptual understanding and procedural fluency to solve the mathematical problems that the teachers are unable to relate them in mathematics learning. Thus, there is a tendency to arise the presence of epistemological obstacles for the students to solve the mathematical problems. 
Russell (2000) states that the students who perform a mathematical procedure without understanding tend to have a wrong mathematical solution as described in the following illustration.

A student named David is given a mathematical problem by the teacher about the multiplication of integers as follows:

$$
\begin{aligned}
& 2 \\
& 57 \\
& \frac{4}{288} \times
\end{aligned}
$$

The first step made by David to solve the problem is multiplying 7 by 4 which equals to 28. After that, David writes 8 and saves 2 above 5. The next step is adding 5 to the previously saved 2 , then multiply it by 4 that he obtains 28 written beside the previous 8 .

Byrnes \& Wasik (1991) argues that a mistake made when performing the procedure occurs due to a poor concept understanding. NCTM (2000) explains that the students who memorize facts or procedures without understanding frequently feel uncertain when or how to apply what they know.

The obtained facts show that conceptual understanding and procedural fluency have not been integrated yet. It is assumed that no effort is made to relate both of them. If the situation is left unsolved, this is afraid that the students may still have the epistemological obstacles in solving the mathematical problems.

The solution offered to develop the students' conceptual understanding and procedural fluency is through Didactic Anticipatory Approach. The Didactic Anticipatory is a learning approach performed by the teachers to adjust the material contents with the students' cognitive aspects (NCTM, 2000; Suryadi, 2010).

The Didactic Anticipatory Approach used in this research is equipped with teaching aids. The Regulation of The Ministry of National Education (2006), states that teaching aids have an important role to improve the effectiveness of learning process in the classroom. This alternative is proposed due to some considerations.

First, Suryadi (2010) suggests that teachers' thinking process in the context of learning has three stages: before, during, and after learning. The Didactic Anticipatory Approach equipped with teaching aids in this research is considered as an approach referring to the first stage of before learning. Before learning is a planning stage learning to anticipate the presence of obstacles experienced by the students in mathematic conceptual understanding and procedural fluency.

Second, considering the learning principles due to the NCTM (2000) document, stating that mathematics learning may facilitate the students in exploring their mathematic understanding through technology. It is asserted that mathematics teaching which utilizes the technological principles is expected to support the students' mathematic conceptual understanding and procedural fluency. Thus, the researcher is interested in conducting a research entitled "Developing the Mathematic Conceptual Understanding and Procedural Fluency through Didactical Anticipatory
Approach equipped with teaching aids in Learning Integers at Junior High School".

\section{RESEARCH METHOD}

The method used in this action research is in the form of Pedagogical Action Research conducted through four stages: observing, planning, acting, and reflecting (Norton, 2009).

The related subjects are the grade VIII students of Junior High School Mujahidin, Pontianak (SMP Mujahidin, Pontianak). The research procedures consist of three stages: preparation, implementation, and final stage.

\section{A. Preparation Stage}

The preparation phase is begun by making instruments for the students' conceptual understanding and procedural fluency equipped with the outline of the questions, alternative solutions of the students' mathematic conceptual understanding and procedural fluency test, scoring guideline, Lesson Plan, Student Activity Sheet and interview guideline. The next step is to conduct the empirical and content validity related to the instruments made.

\section{B. Implementation Stage}

The implementation stage starts by giving pretest to the students as a preliminary phase to observe the students' mathematic conceptual understanding and procedural fluency. the pretest results are then analyzed based on the mathematic conceptual understanding and procedural fluency operational indicators. Subjects with the pretest scores below the Required Minimum Score are treated with a learning utilizing the Didactical Anticipatory Approach equipped with teaching aids followed by posttest to see the given intervention's influence.

\section{Final Stage}

The final stage analyzes the subjects' posttest results, then broken down in detail one by one starting from analyzing the pretest answers up to the posttest answers in tables. Data processing and discussion are then conducted to draw conclusion from the research conducted.

The research data collection is taken by using measurement technique in the form of a written test given to the students and direct communication technique (interview) through a direct contact or verbally face-to-face with the students.

The data analysis technique used to answer the research problems is conducted through three stages: (1) Data reduction; (2) Data presentation; (3) Drawing conclusion (Miles \& Huberman, 1994).

\section{Data Reduction}

There are 14 grade VIII students of Junior High School Mujahidin, Pontianak completed the pretest given. After analyzing the pretest results, the students with the scores below the Required Minimum Score are taken to become the research subjects consisting of nine students: KS, RZ, OV, $\mathrm{DN}, \mathrm{AM}, \mathrm{NC}, \mathrm{SS}, \mathrm{FD}$, and HS. After given the pretest, the 
subjects are interviewed related to the obstacles they have experienced when finishing the pretest given. Furthermore, those nine subjects are given an intervention in the form of learning through the Didactical Anticipatory Approach equipped with teaching aids. A posttest is eventually given to the subjects to see the intervention's influence followed with an interview.

\section{Data Presentation}

In data presentation stage, the conducted process is presenting the results of students' pretest and posttest qualitatively through the epistemological tables and obstacles.

\section{Conclusion}

After data reduction and presentation, the next step is concluding the results obtained during the study related to the students' mathematics conceptual understanding and procedural fluency before and after learning through the Didactic Anticipatory Approach equipped with the teaching aids.

\section{RESULT AND DISCUSSION}

\section{A. Result}

This research starts by giving a pretest to 14 Grade VIII students on July 31 . Of those 14 students, nine people are selected as the research subjects to interview. Pretest and posttest results before and after the subjects are given the learning intervention through the Didactic Anticipatory Approach equipped with the teaching aids presented in Tables I and II.

TABLE I

The RESEARCH SubJeCts' AVERAGE PRETEST AND POSTTEST RESUlts ON MATHEMATICS CONCEPTUAL UNDERSTANDING

\begin{tabular}{|c|c|c|c|}
\hline No & Subject & Pretest Score & Posttest Score \\
\hline 1 & $\mathrm{KS}$ & 40 & 60 \\
\hline 2 & $\mathrm{RZ}$ & 60 & 100 \\
\hline 3 & $\mathrm{OV}$ & 20 & 30 \\
\hline 4 & DN & 20 & 70 \\
\hline 5 & AM & 30 & 60 \\
\hline 6 & $\mathrm{NC}$ & 20 & 50 \\
\hline 7 & SS & 20 & 70 \\
\hline 8 & FD & 20 & 60 \\
\hline 9 & HS & 20 & 70 \\
\hline \multicolumn{2}{|c|}{ Average } & 27.78 & 63.33 \\
\hline
\end{tabular}

The students' epistemological obstacles before given learning intervention of the Didactic Anticipatory Approach, the subjects: (1) not accustomed to asking questions in the form of stories related to the concept of integer multiplication; (2) not accustomed to and experience misconceptions in changing the questions in the form of stories into table representations, number lines, multiple supplementation, and integer multiplication forms; (3) not yet completely identify and connect the important things in the questions in the form of story about integer multiplication; (4) experience misconception in representing the integer multiplication form into multiple supplementation; (5) not yet accustomed to solving the problems using two correct ways; (6) inaccurate in using the mathematical symbols; (7) inaccurate in calculation to solve the mathematical problems; (8) some have not answered the questions.

TABLE III

The Research SubJeCts' Average Pretest and PostTest Results on Mathematics PROCEDURAL FLUENCY

\begin{tabular}{cccc}
\hline No & Subject & Pretest Score & Posttest Score \\
\hline 1 & KS & 66.67 & 66.67 \\
2 & RZ & 66.67 & 83.33 \\
3 & OV & 66.67 & 83.33 \\
4 & DN & 50 & 66.67 \\
5 & AM & 66.67 & 66.67 \\
6 & NC & 66.67 & 100 \\
7 & SS & 16.67 & 100 \\
8 & FD & 83.33 & 83.33 \\
9 & HS & 50 & 100 \\
\multicolumn{7}{c}{ Average } & 50 & 83.33 \\
\hline
\end{tabular}

The students' epistemological obstacles after given the learning intervention of Didactic Anticipatory Approach, the subjects: (1) not yet fully identify and connect the important elements in the questions in the form of stories on integer multiplication; (2) experience misconceptions in representing the integer multiplication idea into multiple supplementation; (3) still inaccurate to make the calculations in solving the mathematical problems; (2) it is still inappropriate to use the mathematical symbols. The conclusion is that the students' epistemological obstacles lessen when compared to those before given the learning intervention of Didactic Anticipatory Approach. However, the students' epistemological obstacles have not been completely resolved.

\section{B. Discussion}

This research reveals the epistemological obstacles experienced by the research subjects and provides the mathematics learning intervention in the form of Didactic Anticipatory Approach equipped with the teaching aids as one alternative to overcome the problems. To completely reveal the epistemological obstacles experienced by the research subjects, pretest is first conducted followed by interview to reveal their prior knowledge on mathematics. From the result of pre-test and conducted interview, it is found that the epistemological obstacles experienced by the research subjects in solving the mathematical problems on integer multiplication.

The epistemological obstacles experienced by the research subjects: (1) less accustomed to asking questions in the form of stories related to the concept of integer multiplication; (2) less accustomed and experience misconceptions in representing the questions in the form of stories into various mathematical representations; (3) only focus on the end result not on the integer multiplication completing processes (4) not completely identify and connect the important elements required to solve the problems in the form of stories; (5) less accustomed to 
completing the mathematical problems using 2 or more resolving ways; (6) use less appropriate mathematical symbols; and (7) perform less appropriate integer calculation procedures. After analyzing the research subjects' epistemological obstacles, the next step is giving the learning intervention of Didactic Anticipatory Approach equipped with teaching aids. One intervention is only given in one meeting and then three observers observe the learning steps using the Didactic Anticipatory Approach.

The learning intervention conducted with the Didactic Anticipatory Approach in this research refers to the NCTM principle (NCTM, 2000) that learning starts by presenting the materials that the students generally know, need, as well as provide challenges and supports to the students who experience the epistemological obstacles in learning in the form of model area teaching aids. In this research, one of teaching aid advantages is because it provides a concrete learning experience for junior high school students to more completely understand the concept and learning not only through oral but also written communication.

This is in line with the Regulation of the Minister of National Education (2006) suggesting that teaching aids have an important role to improve the classroom learning effectiveness. However, teaching aids also have some weaknesses as in this research the area model teaching aids are not quite effective for all education levels, such as at Senior High School (SMA) and higher education (PT) levels. It assumed that this kind of support prevent the students from thinking more abstractly.

After the learning intervention of Didactic Anticipatory Approach equipped with the teaching aids is given to the research subjects, a post-test is conducted and followed with interview to see the influence of the provided intervention. Overall, students' mathematics conceptual understanding and procedural fluency has improved after given the learning intervention of Didactic Anticipatory Approach equipped with the teaching aids due to the comparison between the average pretest and posttest score presented in Table I and Table II. It implies that learning through the Didactic Anticipatory Approach equipped with the teaching aids may improve the students' mathematics conceptual understanding and procedural fluency.

Although the average posttest on the students' mathematics conceptual understanding and procedural fluency has increased, yet it is just a small increase, even the subjects' posttest scores are still below the Required Minimum Scores as presented in Table I for subject KS, OV, $\mathrm{AM}, \mathrm{NC}$, and FD while in Table II for subject DN. The subjects are in facts not yet familiar with the learning intervention of Didactic Anticipatory Approach equipped with the teaching aids. This is in accordance with the statement made Suryadi (2008) who argues that the students' epistemological obstacles are due to the students' dependence on the previous mathematical problem solving experiences. Furthermore, Suryadi explained that the students' epistemological obstacles are not easy to resolve, because not only the learning approach which needs to be well recognized, but also require sufficient time for the subjects to make some adjustments.

Meanwhile, there seems to be more extreme comparison on the students' pretest and post-test scores related to their mathematics procedural fluency. Table II shows that there are some subjects whose scores in both pre-test and post-test do not change (consistent) before and after given the learning intervention of Didactic Anticipatory Approach equipped with the teaching aids as experienced by subject KS, AM, and FD. It quantitatively implies that the learning intervention through the Didactic Anticipatory Approach equipped with the teaching aids does not influence their test results. However, when qualitatively analysed, the result of the subjects' answers and interviews show that the obstacles they experienced have decreased when compared with those before given intervention in the form of learning intervention with Didactic Anticipatory Approach presumably due to their own cognitive conflicts.

The intended cognitive conflict is that the subjects hesitantly implement their knowledge in learning mathematics between the prior and the new knowledge they have just obtained. It is supported by Ismaimuza (2008) stating that cognitive conflict is a conflict between a new cognitive structure (new learned materials) and the explainable environment, but the explanation refers to the initial cognitive structure belonging to each individual. Due to their cognitive conflicts, they eventually experience the epistemological obstacles, which are relatively same before and after given the learning intervention with the Didactic Anticipatory Approach equipped with the teaching aids.

However, when reviewed from the other side, there are subjects experiencing a quite good improvement, reaching the Required Minimum Score and even more shown in Table I experienced by subject RZ, DN, SS, and HS, while in Table II by subject RZ, OV, NC, SS, and HS. It shows that the provided learning intervention through the Didactic Anticipatory Approach equipped with the teaching aids may improve the students' mathematics conceptual understanding and procedural fluency in line with the results of research conducted by Aprilia (2015) and Alfian (2016) suggesting that the Didactic Anticipatory Approach may develop the students' conceptual understanding. Furthermore, Suryadi (2008) also states that the anticipatory model and didactic situation in mathematics learning based on indirect approach generate a good result of the students' well developing diverse mindset to gradually solve the given mathematical problems.

Based on the average pretest and posttest score of students' mathematics conceptual understanding and procedural fluency as presented in Table I and Table II, it shows that the average pretest score is higher than that of the posttest. It indicates that the subjects' mathematics conceptual understanding influences their mathematics procedural fluency. In accordance with the purpose of mathematics learning on procedural fluency, understanding, explaining, and implementing the mathematical concept are previously required (Permendiknas, 2006). Similarly, NRC (2001) states that a good conceptual understanding may 
support the development of procedural fluency in multidigit calculations. Furthermore, NCTM (2014) asserts that there are several reasons regarding to the procedural fluency which depends on conceptual understanding, "to effectively use mathematics, the students should be able to perform the mathematical procedures. They should recognize which procedures are appropriate and most productive in certain situations. What procedures and result types are expected in the implementation of procedures. Without understanding the mathematical bases, the students may frequently make the wrong results".

However, the subjects' weak mathematics procedural fluency may also influence their mathematics conceptual understanding as presented from the pretest scores of subject SS, KS, and AM in Table I and Table II. Some experts from NRC (2001) state "Without sufficient procedural fluency, the students may have some troubles deepening their understanding of mathematical ideas or solving the mathematical problems". Thus, it can be concluded that the mathematics conceptual understanding and procedural fluency are two interrelated components to solve the mathematical problems.

\section{CONCLUSION AND SUGGESTION}

\section{A. Conclusion}

Based on the research results, it can be generally concluded that the mathematics learning through the Didactic Anticipatory Approach equipped with the teaching aids may develop the students' mathematics conceptual understanding and procedural fluency. Specifically, the result of this research can be concluded: (1) based on the the answers given by the research subjects before given the mathematics learning through Didactic Anticipatory Approach equipped with the teaching aids, many epistemological obstacles are still experienced by many students due to their mathematics conceptual understanding indicators: (a) less accustomed to the mathematical questions in the form of stories; (b) less accustomed and experience misconceptions in representing the mathematical problems in the form of stories into table representations, number lines, multiple supplementation, and multiplication forms; (c) not completely identify and connect the important information contained in the mathematical problems; (d) less accustomed to represent integer multiplication into multiple supplementation. After the intervention is given, the students' epistemological obstacles have reduced but not completely resolved. (2) based on the answers given by the research subjects before given the mathematics learning with the Anticipatory Approach Didactic equipped with the teaching aids, the students still experience many epistemological obstacles due to their mathematics procedural fluency indicators: (a) the students are less accustomed to solving the math problems using two or more resolving ways; (b) the students do not carefully make the calculation and use the mathematical symbols in solving the math problems. After the intervention is given, the students' epistemological obstacles have reduced, yet not completely resolved. (3) based on the answers given by the research subjects after given the mathematics learning through the Didactic Anticipatory Approach equipped with the teaching aids, the average score is higher than that before given the learning intervention through the Didactic Anticipatory Approach equipped with the teaching aids. This statement is supported by the decreasing epistemological obstacles experienced by the research subjects after given the mathematics learning through the Didactic Anticipatory Approach equipped with the teaching aids.

\section{B. Suggestion}

Some suggestions are proposed based on the research findings: (1) the mathematics teachers should consider the results of this research and use it as a reference in learning mathematics focusing on didactic triangles. (2) the other researchers who are interested in conducted further researches related to this topic, should provide the complete Didactic Anticipatory Approach in developing the students' conceptual understanding and procedural fluency, at least the research subjects may obtain the posttest scores of $\geq$ the Required Minimum Score. (3) The learning intervention given in this research is still less effective for the learning processes in senior high school and college level students as their level of thinking has become abstract, while the teaching aids are concrete.

\section{REFERENCES}

Alfian, H. 2016. Mengatasi Hambatan Pemahaman Konseptual Matematis Siswa dengan Pendekatan Antisipasi Didaktis Materi Dalil Pythagoras di Sekolah Menengah Pertama. Skripsi. Fakultas Keguruan dan Ilmu Pendidikan, Pontianak.

Aprilia, M. 2015. Mengatasi Kesulitan Pemahaman Konseptual Siswa dengan Pendekatan Antisipasi Didaktis dalam Materi Operasi Penjumlahan Pecahan di Kelas VII SMP Negeri 10 Pontianak. Skripsi. Fakultas Keguruan dan Ilmu Pendidikan, Pontianak.

Byrnes \& Wasik. 1991. Role of Conceptual Knowledge in Mathematical Procedural Learning. Developmental Psychology, 27, 777-786.

Chadwick, D. 2009. Approaches to Building Conceptual Understanding, New Zealand: Developed and edited for the Ministry of Education by Learning Media Limited.

Isleyen. T., \& Isik. A. 2003. Conceptual and Procedural Learning in Mathematics. Journal of the Korea Society of Mathematical Education Series D: Research in Mathematical Education, 7, 91-99.

Ismaimuza. D. 2008. Pembelajaran Matematika dengan Konflik Kognitif. [Online]. Available: http://core.ac.uk/download/pdf/11064525pdf.

McClure, L. 2014. Developing Number fluency, What, Why and How accessed. [Online]. Available: http://nrich.maths.org/10624

Miles, M \& Huberman, A. 1994. Qualitative Data Analysis. USA: Library of Congress Cataloging-in-Publication Data. 
NAEP. 2002. Mathematics Framework for the 2003 National Assessment of Educational Progress. Washington, DC: National Assessment of Educational Progress.

NCTM. 2000. Principles and Standards for School Mathematics, USA: The National Council of Teachers Matematics, Inc.

NCTM. 2014. Principles to Actions Ensuring Mathematical Success for All, USA: The National Council of Teachers Matematics, Inc.

Norton, L.S. 2009. Action Research in Teaching and Learning: A practical guide to conducting pedagogical research in universities. USA: Routledge.

NRC. 2001. Adding it up: Helping children learn mathematics. Washington, DC: National Academy Press.
Permendiknas. 2006. Standar Isi untuk Satuan Pendidikan Dasar dan Menengah. Jakarta: BSNP.

Russell, S. 2000. Developing Computational Fluency With Whole Numbers In The Elementary Grades. Cambridge: Education Research.

Suryadi, D. 2010. Penelitian Pembelajaran Matematika untuk Pembentukan Karakter Bangsa. Makalah pada Seminar Nasional Matematika, Yogyakarta: UNY.

Suryadi, dkk. 2008. Model Antisipasi dan Situasi Didaktis Dalam Pembelajaran Matematika Kombinatorik Berbasis Pendekatan Tidak Langsung. Bandung: UPI.

Walle V.D., John A., Karp, K.S., \& Bay-Williams, Jennifer, M. 2010. Elementary and Middle School Mathematics Teaching Developmentally, USA: Pearson Education, Inc. 